\title{
SALINATION OF SNOW ON SEA ICE AND FORMATION OF SNOW ICE
}

\author{
by
}

\author{
TAKATOSHI TAKIZAWA
}

Institute of Low Temperature Science, Hokkaido University, Sapporo, Japan 060

\section{ABSTRACT}

Field experiments were carried out to investigate a change in salinity of the snow cover on sea ice and of the snow ice. Snow which covered thin sea ice was flooded with the brine that was pushed out onto the sea ice surface, resulting in a rise in salinity to more than $32 \%$, which was higher than that of sea water. On the day after the salination of the snow, the flooded snow was found to have been either frozen into snow ice or kept unfrozen. In either case the brine was excluded in turn from the flooded snow. As a result, the wet snow or snow ice had a salinity somewhat above $20 \%$. It is suggested that subsequently the wet snow keeps the salinity at more than $20 \%$, while the salinity of the snow ice decreases gradually with time.

\section{INTRODUCTION}

It is known that brine of high salinity is present at the surface of thin sea ice, and hence the ice surface is always wet (Zubov 1945, Ono and others 1980). The surface brine is sucked up by capillary action into snow which covers the sea ice. Furthermore, the snow weight depresses the ice, with the resultant rise in waterline. Consequently the brine contained inside the ice body is pushed out onto the surface, to be sucked up additionally into the snow. Thus, the wetness and salinity of the snow increases. Wet snow and slush (snow holding much brine) in many cases refreezes and changes to snow ice. However, there are only a few investigations into the characteristics of snow ice and snow on sea ice (Martin 1979; Takizawa and Wakatsuchi 1982; Takizawa 1983).

This paper describes the results of field experiments conducted to clarify the salinity of the snow cover on sea ice and the formation of snow ice.

\section{OBSERVATIONS}

\section{Observation method}

The experiments were carried out at Lake Saroma in Hokkaido, Japan, February 1982 to 1984. The lake, a large lagoon, is covered with flat sea ice in winter. A test pool $(2 \mathrm{~m} \times 2 \mathrm{~m})$ was made by removing ice blocks from the fast ice sheet. The salinities of newly formed ice in the pool and of the snow covering it were determined. Salinity of the snow cover on the fast ice was also measured.

Snow cover on the ice grown in the pool

In 1983 the test pool began to freeze on the evening of 5 February. On the morning of 6 th newly-formed ice was $25 \mathrm{~mm}$ thick, its the upper layer snow ice due to snowfall at night (Figure 1). The snow cover was $5 \mathrm{~mm}$ deep and flooded with brine. The snow had the salinity of $32.5 \%$, higher than that of sea water $(30.68 \%$ \% $)$. On the following morning, the wet snow was found to have frozen into a snow ice with salinity $21.9 \%$. This decrease in salinity indicates that a fair amount of brine was excluded while the snow ice formed. Subsequently the snow ice kept salinity of more than $20 \%$. On the morning of the 10 th the ice was covered with snow $75 \mathrm{~mm}$ deep. The lower layer of the snow cover was flooded and its salinity was also as high as $32.2 \%$. On the 11 th the wet snow did not freeze, and its salinity was found to have decreased to $21.6 \%$ oo.
It is noted that the dry snow contained salt, though the amount was fairly small. This is believed to be due to the contamination of snow samples at the time when they were collected.
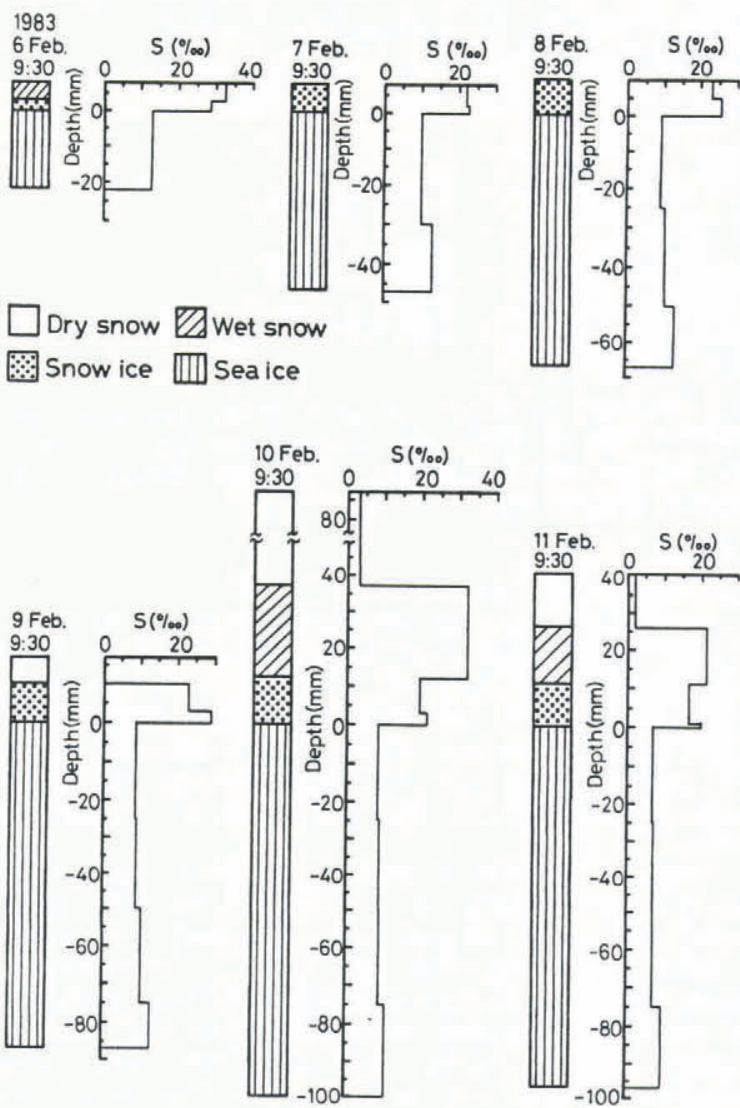

Fig.1. Changes in salinity of snow cover and ice in the pool, February 1983.
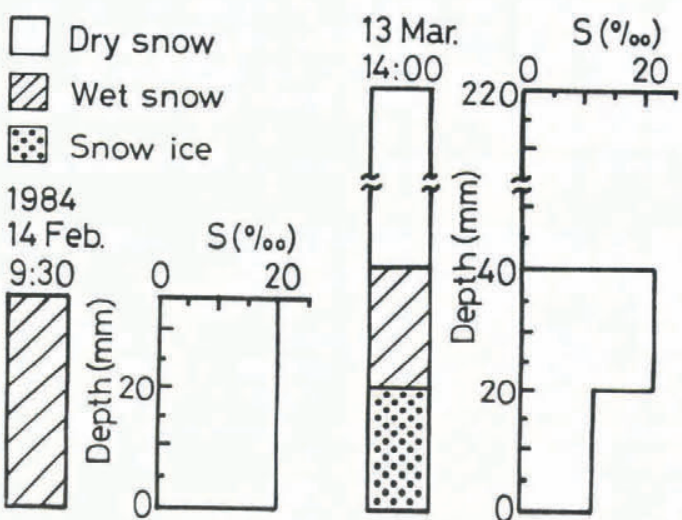

Fig.2. Salinity profiles of snow cover and snow ice on sea ice in the pool in 1984. The thickness of sea ice was $0.078 \mathrm{~m}$ on 14 February and $0.225 \mathrm{~m}$ on 13 March. 
Salinity profiles of the snow and snow ice on the pool ice on 14 February and 13 March 1984 are illustrated in Figure 2. The snow on 14 February was wet to full depth. After one month, on 13 March, the lower layer of the wet snow was found to have changed to snow ice having the salinity of $12 \%$. It is reasonable to expect that the snow ice, just after it was formed, had the salinity of about $20 \%$ by the analogy to the change from the wet snow to the snow ice shown in Figure 3. This low value of salinity therefore suggests that it decreased gradually with time. Meanwhile the wet snow still kept a salinity of more than $20 \%$ oo.

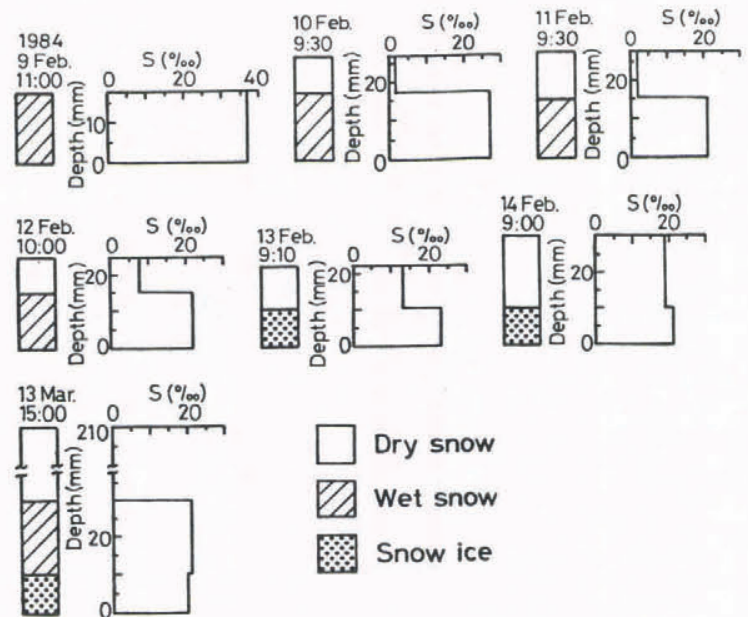

Fig.3. Changes in salinity of snow cover and snow ice on the fast ice in 1984. The thickness of fast ice was 0.21 $\mathrm{m}, 0.22 \mathrm{~m}$ and $0.32 \mathrm{~m}$ on 9 and 14 February and 13 March, respectively.

\section{Snow cover on the fast ice}

Snow samples were collected at several stations on the fast ice in 1982 and 1983. The salinities of wet snow and slush are listed in Table 1 . The wet snow had a salinity of more than $20 \%$ at every station except Station 83-2, where the slush located between the wet snow and the ice had the high salinity of $23.3 \%$ though the salinity of the wet snow was lower than $20 \%$.

Figure 3 shows a change in snow salinity with time. On the morning of 9 February the fast ice was covered with snow $18 \mathrm{~mm}$ deep. The snow was wet and its salinity was as high as $37 \%$. Thereafter the salinity decreased rapidly and fell to $21 \%$ on the 11 th The wet snow changed to snow ice on the 13th. The salinities of wet snow and snow ice were almost constant from the 11th to the 14th. One month later, on 13 March, the wet snow and snow ice had the salinity of $21 \%$ and $20 \%$ respectively. As for the latter, the salinity was almost the same as one month before, whereas the salinity of snow ice in the pool decreased to as low as $12 \%$ on the same day (see Figure 2). This discrepancy is inexplainable to our satisfaction because of a lack of observation data around 13 March.

It is noticeable that from 12 to 14 February the

TABLE 1. SALINITIES OF WET SNOW AND SLUSH ON THE FAST ICE (1982 AND 1983).

\begin{tabular}{llcccc}
$\begin{array}{c}\text { Station } \\
\text { no }\end{array}$ & $\begin{array}{c}\text { Fast ice } \\
\text { thickness } \\
(\mathrm{m})\end{array}$ & $\begin{array}{c}\text { Wet snow } \\
\text { Depth } \\
(\mathrm{mm})\end{array}$ & $\begin{array}{c}\text { Salinity } \\
(\% \circ)\end{array}$ & $\begin{array}{c}\text { Septh } \\
(\mathrm{mm})\end{array}$ & $\begin{array}{c}\text { Salinity } \\
(\% \circ)\end{array}$ \\
\hline $82-1$ & 0.26 & 30 & 23.5 & & \\
$82-2$ & 0.255 & 25 & 26.6 & & \\
$82-3$ & 0.25 & 25 & 36.9 & & \\
$83-1$ & 0.237 & 10 & 22.7 & & \\
$83-2$ & 0.18 & 65 & 16.0 & 25 & 23.3 \\
\hline
\end{tabular}

dry snow had high salinities, particularly reaching as high as $19 \%$ on the 14 th. It is considered that this is because the dry snow really contained much salt, and not attributable to the contamination of snow samples when they were taken.

\section{CONCLUSION}

When a thin sea ice is covered with snow, the snow cover is flooded with the brine which is pushed out onto the ice surface. Thus it has the salinity higher than that of sea water. The flooded snow is found next day having frozen into snow ice in some cases. During this time brine exclusion from the snow takes place whether the snow ice is formed or not. As a result, the wet snow or the snow ice has the salinity of a little above $20 \%$. Thereafter the wet snow keeps the salinity of more than $20 \%$. On the other hand, a possibility is suggested that the brine in the snow ice is excluded gradually with time.

\section{ACKNOWLEDGEMENTS}

The author gratefully acknowledges the assistance of T Kawamura, $M$ Oi, $M$ Ishikawa and $H$ Fukushi of Sea Ice Research Laboratory in the field work. He also expresses his gratitude to Professor N Ono for his useful comments and critical reading of the manuscript. This work was partly supported by the Grant-in-Aid for Fundamental Scientific Research (56460037) from the Japanese Ministry of Education.

\section{REFERENCES}

Martin S 1979 A field study of brine drainage and oil entrainment in first-year sea ice. Journal of Glaciology 22(88): 473-502

Ono N, Wakatsuchi M, Kawamura T 1980 Freezing phenomena at seawater surface opening in polar winter I. Low Temperature Science A39: 159-166

Takizawa T, Wakatsuchi M 1982 Snow layer on sea ice. Low Temperature Science A41: 159-165

Takizawa T 1983 Characteristics of snow cover on sea ice and formation of snow ice. Low Temperature Science A42: 157-162

Zubov N N 1945 L'dyarktiki [Arctic ice]. Izdatel'stvo Glavsevmorputi, Moscow 